\title{
Genetic variability of Hepatitis C Virus in Moroccan population
}

\author{
Ikram Brahim*, Abdelah Akil, El Mostafa Mtairag, Régis Pouillot, Abdelouhad El Malki, Richard Njouom, \\ Pascal Pineau, Sayeh Ezzikouri, Soumaya Benjelloun, Salwa Nadir, Rhimou Alaoui \\ From 17th International Symposium on HIV and Emerging Infectious Diseases (ISHEID) \\ Marseille, France. 23-25 May 2012
}

Hepatitis $\mathrm{C}$ virus (HCV) evolution is a highly dynamic process. There is little information about molecular epidemiology of $\mathrm{HCV}$ isolates in Morocco, an area known for an intermediate prevalence of $\mathrm{HCV}$ infection.

The primary aim of this study was to determine the subgenotype distribution of $\mathrm{HCV}$ strains in patients with chronic $\mathrm{HCV}$ infection in Morocco and an eventual association between HCV subgenotypes and liver cancer. The secondary aim was to estimate the prevalence of amino acid substitutions in the $\mathrm{HCV}$ core region in treatment-naive patients from Morocco and an eventual association between amino acid substitutions and liver cancer.

Serum samples from a total of 185 anti-HCV positive patients were included in this study (81 males and 104 females). The identification of HCV genotype and subtype was respectively performed by sequencing of the 5'UTR and core regions and phylogenetic analysis of the NS5B region. HCV demographic history was inferred using a Bayesian Monte Carlo Markov chain analysis. Of the 174 patients with detectable viremia, the core and the NS5B regions were amplified in $152(87.4 \%)$ and 141 (81.0\%) patients respectively. Phylogenetic analysis based on NS5B region revealed that most $\mathrm{HCV}$ strains were classified into subtypes $1 \mathrm{~b}(75.2 \%)$ followed by subtypes $2 \mathrm{i}(19.1 \%), 2 \mathrm{k}$ (2.8\%). Subtypes $2 \mathrm{a}, 1 \mathrm{a}$, and $4 \mathrm{a}$ were found in a single patient. HCV subtype $1 \mathrm{~b}$ had an even higher prevalence in liver cancer cases $(84.4 \%$ vs $67.5 \%$ in chronic hepatitis, $\mathrm{P}=$ 0.031). Using a Bayesian approach, the mean date of appearance of the most recent common ancestor was estimated to be 1910 for HCV-1b and 1854 for HCV-2i. Based on core region, mutations at R70Q or L91M were

* Correspondence: ikrambrahim@gmail.com

Faculty of Sciences Ain Chock Casablanca, Casablanca, Morocco detected in more than one fourth of patients infected with HCV $1 b$.

Published: 25 May 2012

\section{doi:10.1186/1742-4690-9-S1-P50}

Cite this article as: Brahim et al:: Genetic variability of Hepatitis C Virus in Moroccan population. Retrovirology 2012 9(Suppl 1):P50.
Submit your next manuscript to BioMed Central and take full advantage of:

- Convenient online submission

- Thorough peer review

- No space constraints or color figure charges

- Immediate publication on acceptance

- Inclusion in PubMed, CAS, Scopus and Google Scholar

- Research which is freely available for redistribution
C Biomed Central

\section{() Biomed Central}

(c) 2012 Brahim et al; licensee BioMed Central Ltd. This is an Open Access article distributed under the terms of the Creative Commons Attribution License (http://creativecommons.org/licenses/by/2.0), which permits unrestricted use, distribution, and reproduction in any medium, provided the original work is properly cited. 